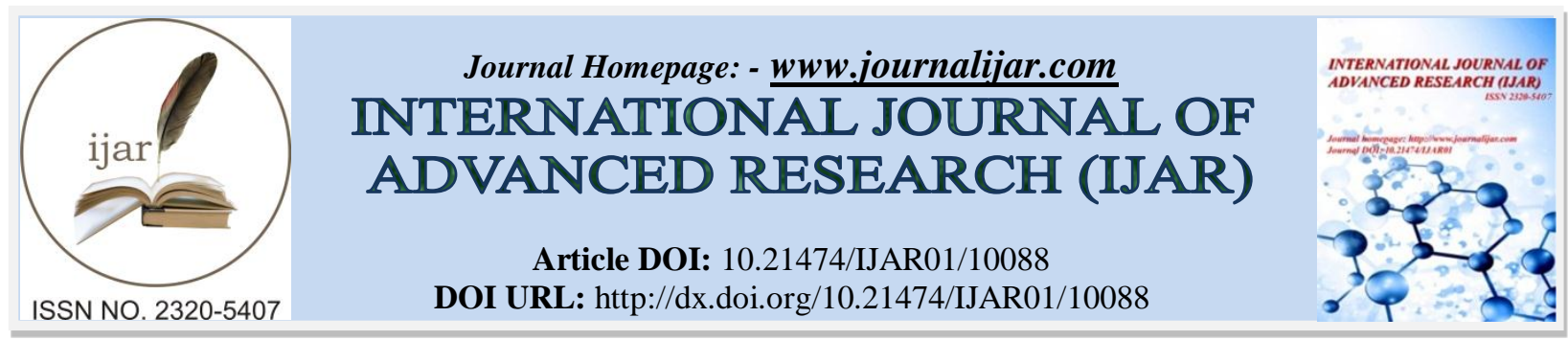

RESEARCH ARTICLE

\title{
A STUDY ON ROLE OF FII \& FDI IN INDIAN ECONOMIC GROWTH.
}

\author{
Ajinkya P Patil.
}

\section{Manuscript Info}

Manuscript History

Received: 14 September 2019

Final Accepted: 16 October 2019

Published: November 2019

Key words:-

fdi, fii, economic growth and gdp.

\begin{abstract}
In 1991 industrial policy, has brought new dimensions to the indian economy through globalization. The basic motto like selfsustainability, domestic savings and infrastructure development were replaced by robust economic growth since a decade. Global trade vanished the cross borders and paved the way for international business. Being most populous country, india is facing many challenges that hampering the growth of economy like societal and financial factors. Deficit in trade, interest rates, inflation are a part of them. Indian economy was influencing by western countries through their investments in to the financial system. Thus, the sources of foreign capital like fdi, fii were become dominant players in capital formation as well as risky too. These investments were welcomed through direct participation in production areas or investing in stock exchanges. Recently, it is evident from the rbi statistics that majority of the capital sources are from foreign countries. This would definitely effect the financial system and economy as a whole. Current research paper focusing on the effect of these factors on indian economy. For this purpose, researcher had taken gdp as growth indicator and the factors like fdi and fii were chosen as independent variables.
\end{abstract}

Copy Right, IJAR, 2019,. All rights reserved.

\section{Introduction:-}

The recent history of indian financial system shown the stubborn growth in terms of its horizontal and vertical integrating activities. This was happened only because of the introduction of foreign capital in to indian financial system. India being one of the great developing countries, marked its own way in developing and structuring a transparent, stable and innovative financial system across the globe. These caused to raise the economic growth resulting a double digit growth rate since a decade. These foreign investments are helpful not only for the developing countries, developed countries too. Various economists proved that fdi and fii were attracted by india due to the reasons like availability of raw materials, man power and infrastructure facilities at low cost. These investments are allowed to invest in india through direct investment/participation in the company activities or through stock exchanges. Fdi can invest directly in to the company and can have control and influence the activities of the business. Whereas, fii investments are tuned only to the stock exchanges. Fdi not only encourages gathering of capital to the country, it also encourages skills, bringing technology to the host country and also creates sources of employment. These benefits caused fdi to focus more than fii in the capital formation.

World economic forum came out with the global competitiveness report 2016- 2017 as per which switzerland continues to top the overall ranking in global competitive index (gci), characterized by an excellent capacity for innovation and a very sophisticated business culture. Sweden has moved ahead of singapore and united states to 
claim 2nd position this year. Singapore, united states, netherland and germany round out the top five continue to prevail in the top 10 with japan, finland, sweden, hong kong and united kingdom following suit. After having fallen four positions over the past two years, the united kingdom moves up one spot to 10th place this year, with a stable performance.

Bric ranking for 6 pillars:

\begin{tabular}{|c|c|c|c|c|c|}
\hline No & Pillars & Brazil & Russia & India & China \\
\hline 1 & Received foreign & 13 & 16 & 20 & 4 \\
\hline & Investment & & & & \\
\hline 2 & Exports & 6 & 8 & 12 & 1 \\
\hline 3 & Imports & 21 & 17 & 8 & 2 \\
\hline 4 & Foreign exchange & 8 & 7 & 9 & 1 \\
\hline & Reserve & & & & \\
\hline 5 & Gdp(nominal) & 8 & 15 & 7 & 2 \\
\hline 6 & Gdp(ppp) & 7 & 6 & 3 & 1 \\
\hline
\end{tabular}

(source:-2016-17world economy report)

Here we show in table 1 bric ranking here we see the china economy during 2016-17 very strong and high import export and foreign exchange reserve and gdp rate also high and also see that world highest economy. India is gdp are high and good to brazil and russia but compares to china, brazil and russia we less received foreign investment. China export are more compare to import in $2^{\text {nd }}$ and export in $1^{\text {st }}$ number so its show china's economy condition are very good and attractive to investor but in india exports are less and rank are 12 and import is 8 so our economy are in deficit and high of our import and export rate because that our economy is slow down that's less foreign investor to invest our country compare to china.

\section{Foreign direct investment:}

Foreign direct investment may be of any of the form like long-term, short-term capital and equity. It does not include the purchase of shares. Fdi enhance employment opportunities and skills, innovations, technology support to the company with their expertise. India become the favor most destination due to the following reasons:

1. Availability of abundant raw materials

2. High interest rates for investments

3. Tax regimes

4. Ease of transactions

The fdi may also affect due to the government trade barriers and policies for the foreign investments and leads to less or more effective towards contribution in economy as well as gdp of the economy (mahanta devajit, 2012).

Even though some of the developed and developing countries offering very high interest rates than india, foreign investors are not willing to invest in risky avenues. Fii and fdi are very essential for the indian economic growth. Fdi encourages economic development through direct involvement whereas fii provide liquidity for those stock issued by the company. These acts as catalyst in the race of global economies. Unlike fii, fdi is said to be stable capital. Most of the critics faced by fii are being sensitive and creates volatility in the secondary market. But due to the expertise knowledge and means of trading, analytical technology, they are making profits out of the stock exchanges. These on the other hand enhances the value of the firm by fixing the price for the shares thus caused to raise the liquidity and demand for the stock as a result net worth will groom. The sectoral limit for fdi can be understand from the following.

\section{Sector wise cap limit for fdi:}

$$
\text { Sector }
$$

Cap limit 


\begin{tabular}{|l|l|}
\hline Agriculture and animal husbandry & $100 \%$ \\
\hline Plantation sector & $100 \%$ \\
\hline Mining & $100 \%$ \\
\hline Petroleum and natural gas & $100 \%$ \\
\hline Psu & $49 \%$ \\
\hline Manufacturing & $100 \%$ \\
\hline Defense & $100 \%$ \\
\hline Broadcasting carriage services & $100 \%$ \\
\hline Content services & $49 \%$ \\
\hline Print media & $26 \%$ \\
\hline Publishing and printing & $100 \%$ \\
\hline Civil aviation & $100 \%$ \\
\hline Construction developments & $100 \%$ \\
\hline Industrial parks & $100 \%$ \\
\hline Satellites establishment and operations & $100 \%$ \\
\hline Private security agencies & $74 \%$ \\
\hline Telecom services & $100 \%$ \\
\hline E- commerce & $100 \%$ \\
\hline Single brand retail trading & $100 \%$ \\
\hline Multi brand & $51 \%$ \\
\hline Railways infrastructure & $100 \%$ \\
\hline Banking private sector & $74 \%$ \\
\hline Insurance & $49 \%$ \\
\hline Pension sector & $49 \%$ \\
\hline Power exchanges & $49 \%$ \\
\hline White label atm operations & $100 \%$ \\
\hline Financial services & $100 \%$ \\
\hline Pharmaceuticals & $100 \%$ \\
\hline Sour & \\
\hline ins consoldat & $19 \%$ \\
\hline
\end{tabular}

Source: dipp, consolidated fdi policy, august 28, 2017.

Top 10 sources of fdi flow to india during 2000-2017:

\begin{tabular}{|l|l|l|l|}
\hline Rank & Name of the country & Fdi (in rs. Crores) & \% of inflow \\
\hline 1 & Mauritius & 659539.33 & 34.45 \\
\hline 2 & Singapore & 349147.08 & 16.76 \\
\hline 3 & Japan & 148377.72 & 7.45 \\
\hline 4 & United kingdom & 129692.24 & 6.97 \\
\hline 5 & Netherlands & 127464.64 & 6.33 \\
\hline 6 & Usa & 119075.08 & 6.06 \\
\hline 7 & Germany & 58064.81 & 2.98 \\
\hline 8 & Cyprus & 48159.87 & 2.62 \\
\hline 9 & France & 32599.08 & 1.69 \\
\hline 10 & Uae & 27767.83 & 1.39 \\
\hline
\end{tabular}

Source: dipp official website, fdi statistics.

\section{Foreign institutional investors:}

Fii is an institutional body situated in a foreign country and invest in domestic country through stock markets. Fdi and fii activities are go hand by hand. Fii provide liquidity and value based trading, price fixing of the shares that are issued by the company. Fii plays a vital role in stock markets and causes market volatility. This embosses a larger effect on domestic financial markets like stock market, money markets and foreign exchange markets.

\section{Growth of fii}




\begin{tabular}{|l|l|l|l|}
\hline $2008-09$ & \multicolumn{1}{|c|}{-47706} & \multicolumn{1}{|c|}{1895} & \multicolumn{1}{|c|}{-45811} \\
\hline $2009-10$ & 110221 & 32438 & 142658 \\
\hline $2010-11$ & 110121 & 36317 & 146438 \\
\hline $2011-12$ & 43738 & 49988 & 93726 \\
\hline $2012-13$ & 140033 & 28334 & 168367 \\
\hline $2013-14$ & 79709 & -28060 & 51649 \\
\hline $2014-15$ & 111333 & 166127 & 277461 \\
\hline $2015-16$ & -14172 & -4004 & -18176 \\
\hline $2016-17$ & 55703 & -7292 & 48411 \\
\hline $2017-18$ & 25635 & 119036 & 144682 \\
\hline
\end{tabular}

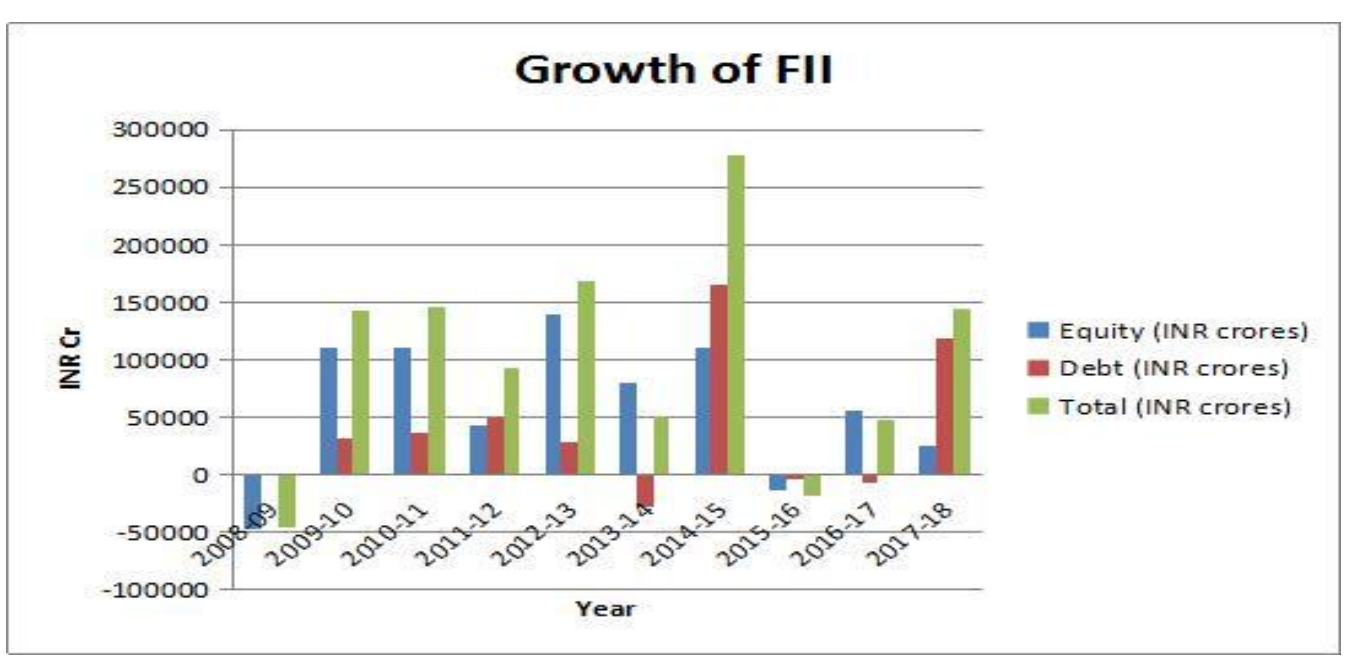

\section{Growth of fii:}

From the above table its indicate that in year 2008-09 fii withdraws all money from capital market, because of recession in global market. Further from year 2009-10, 2010-11\& 2011-12 investment done by fii increased in both equity \& debt market.

In year 2012-13 fii invested more in equity market as compared to debt market. There were again ups \& downs in both market which show the volatility of Market.

\section{Net investment by fii last 10 year:}

\begin{tabular}{|l|l|}
\hline \multicolumn{1}{|c|}{ Year } & Net investment \\
\hline 2008 & 66179 \\
\hline 2009 & -45811 \\
\hline 2010 & 142658 \\
\hline 2011 & 146438 \\
\hline 2012 & 93726 \\
\hline 2013 & 168367 \\
\hline 2014 & 51649 \\
\hline 2015 & 277461 \\
\hline 2016 & -18176 \\
\hline 2017 & 48411 \\
\hline
\end{tabular}




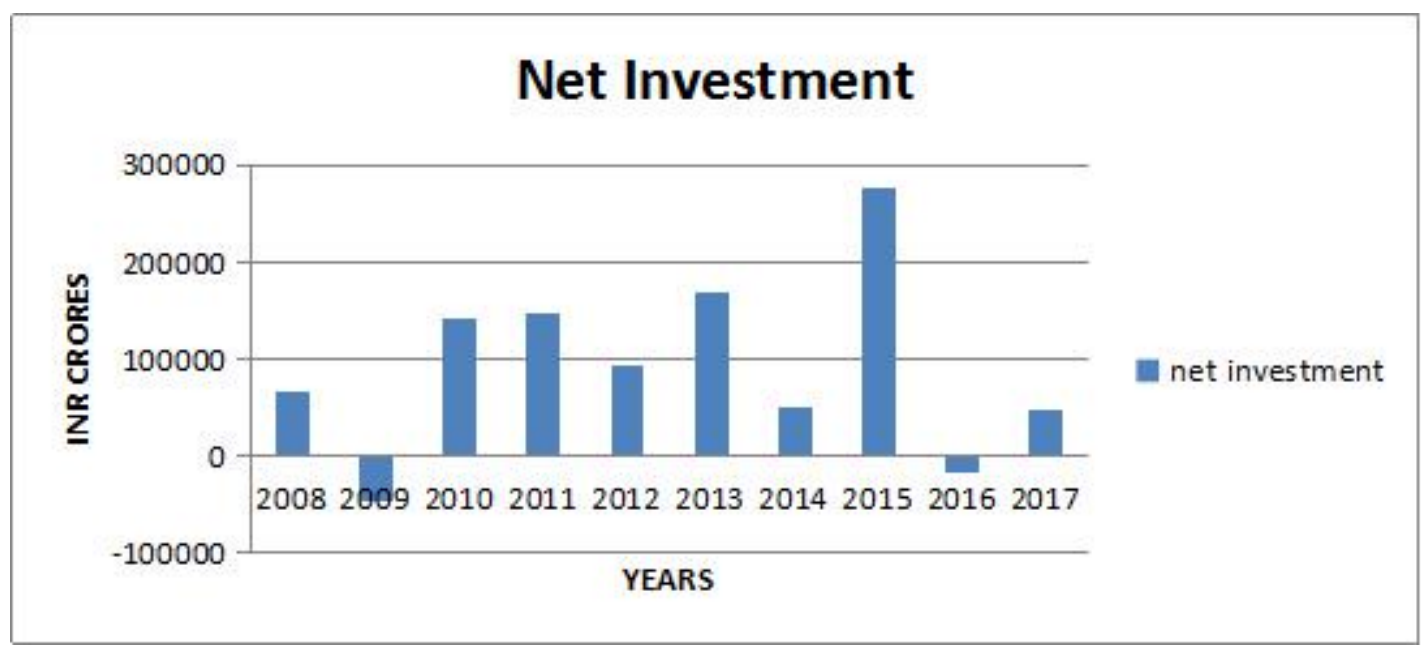

\section{Chart 2net investment:}

From the above table it's indicating that in year 2009 net investment withdraws all money from capital market; because of recession in global market. Further from year 2010,2011, 2013, 2014investment done by fii increased in both capital markets in 2015 it was highest to 277461 crores.

There were again ups \& downs in both markets which show the volatility of market.

\section{Limits on fii to invest in india:}

The reserve bank of india monitors the ceilings on fii/nri/pio investments in indian companies on a daily basis. For effective monitoring of foreign investment ceiling limits, the reserve bank has fixed cut-off points that are two percentage points lower than the actual ceilings. The cut-off limit for companies with 24 per cent ceiling is 22 per cent and for companies with 30 per cent ceiling, is 28 per cent and so on. Similarly, the cut-off limit for public sector banks (including state bank of india) is 18 percent.

Once the aggregate net purchases of equity shares of the company by fiis reach the cut-off point, which is $2 \%$ below the overall limit, the reserve bank cautions all designated bank branches so as not to purchase any more equity shares of the respective company on behalf of fiis without prior approval of the reserve bank. The link offices are then required to intimate the reserve bank about the total number and value of equity shares/convertible debentures of the company they propose to buy on behalf of fiis on receipt of such proposals, the reserve bank gives clearances on a first-come-first served basis till such investments in companies reach 30/40/49 per cent limit or the sectoral caps/statutory ceilings as applicable. On reaching the aggregate ceiling limit, the reserve bank advises all designated bank branches to stop purchases on behalf of their fiis clients. The reserve bank also informs the general public about the 'caution' and the 'stop purchase' in these companies through a press release.

\section{Companies in which fii investment is allowed up to $30 \%$ of their paid up capital:}

\begin{tabular}{|l|l|}
\hline 1. & Asian paints (india) Itd \\
\hline 2. & Capital trust Itd. \\
\hline 3. & Divi's laboratories Itd \\
\hline 4. & Ferro alloys corporation Itd. \\
\hline 5. & Garware polyester Itd. \\
\hline 6. & Givo Itd. (formerly kb\&t Itd.) \\
\hline 7. & Orchid chemicals and pharmaceuticals Itd \\
\hline 8. & Penta soft tec(pentafour communications Itd) \\
\hline 9. & Polyplex corporation Itd \\
\hline 10. & Ranbaxy laboratories Itd \\
\hline 11. & Shasun chemicals Itd \\
\hline 12. & Sonata software Itd \\
\hline 13. & The paper products Itd \\
\hline
\end{tabular}




\begin{tabular}{|l|l|}
\hline 14. & Vikas wsp Itd. \\
\hline 15. & Software solutions integrated Itd \\
\hline
\end{tabular}

( source :- reserve bank of india 2018 https://rbi.org.in/scripts/bs_fiiuser.aspx )

Companies in which fii investment is allowed upto $40 \%$ of their paid up capital:

\begin{tabular}{|l|l|}
\hline 1. & Adlabs films ltd. \\
\hline 2. & Aftek infosys ltd. \\
\hline 3. & Balaji telefilms ltd. \\
\hline 4. & Bharat forge ltd \\
\hline 5. & Burr brown (india )ltd \\
\hline 6. & Cipla ltd. \\
\hline 7. & Elbee services ltd \\
\hline 8. & Gujarat ambuja cements ltd \\
\hline 9. & Heg ltd \\
\hline 10. & Jindal steel \& power ltd \\
\hline
\end{tabular}

( source :- reserve bank of india 2018 https://rbi.org.in/scripts/bs_fiiuser.aspx )

Companies in which fii investment is allowed upto $49 \%$ of their paid up capital:

\begin{tabular}{|l|l|}
\hline 1. & Alok industries \\
\hline 2. & Auribindopharma Itd. \\
\hline 3. & Arvind mills Itd \\
\hline 4. & Balakrishna industries Itd \\
\hline 5. & Blue dart express Itd \\
\hline 6. & Crisil \\
\hline 7. & Digital globalsoft Itd. \\
\hline 8. & Dr. Reddy's laboratories Itd. \\
\hline 9. & D. S. Kulkarni developers Itd. \\
\hline 10. & Financial technologies (i) Itd \\
\hline
\end{tabular}

( source :- reserve bank of india 2018 https://rbi.org.in/scripts/bs_fiiuser.aspx )

companies in which fii investment is allowed upto sectoral cap/statutory ceiling of their paid up capital:

\begin{tabular}{|l|l|}
\hline 1. & Amtek auto Itd (74\%) \\
\hline 2. & Advanta india Itd (49\%) \\
\hline 3. & Amtek india Itd (74\%) \\
\hline 4. & Ahmednagar forgings Itd (74\%) \\
\hline 5. & Anant raj industries Itd. (40\%) \\
\hline 6. & Ang auto Itd (49\%) \\
\hline 7. & Apollo hospitals (74\%) \\
\hline 8. & Apollo hospitals (74\%) \\
\hline
\end{tabular}

( source :- reserve bank of india 2018 https://rbi.org.in/scripts/bs_fiiuser.aspx )

Companies in which fii investment is $100 \%$ allowed:

\begin{tabular}{|l|l|}
\hline 1. & Aztec software and technology services Itd $-(100 \%)$ \\
\hline 2. & Educomp solution Itd $(100 \%)$ \\
\hline 3. & Gateway distriparks Itd $-(100 \%)$ \\
\hline 4. & Geodesic information systems Itd- $(100 \%)$ \\
\hline 5. & Geometric software solutions Itd $-(100 \%)$ \\
\hline
\end{tabular}

( source :- reserve bank of india 2018 https://rbi.org.in/scripts/bs_fiiuser.aspx )

Correlation between fdi, fii and gdp:

Correlation matrix

Variables

Gdp(in cr.rs)

Fdi (in cr. Rs)

Fii (in cr. Rs.) 


\begin{tabular}{|l|l|l|l|}
\hline Gdp(in cr.rs) & 1 & 0.882 & 0.018 \\
\hline Fdi(in cr.rs) & 0.882 & 1 & -0.032 \\
\hline Fii(in cr.rs) & 0.018 & -0.032 & 1 \\
\hline
\end{tabular}

Values in bold are different from 0 with a significance level alpha $=0.05$

\section{Significance of correlation coefficient:}

Coefficient of correlation(r), ranges from -1 to +1 positive vales exceeding 0.5 denotes the strong relation between the variables, whereas the values for ' $r$ ' less than 0.5 represents a weak relation among the variables. The sign indicates the direction of relation. If it is positive indicates the increase in the other variable vice versa. The negative sign indicates the increase in the value of one variable causes decrease in the value of other variable. Present value for ' $\mathrm{r}$ ' between fdi and gdp is 0.882 which resembles the strong relation. Whereas, the correlation coefficients ' $r$ ' between fii and gdp is 0.018 which is very week. Un intentionally, here the ' $r$ ' value between fdi and fii is inversely related. But the strength of the relation is very weak. Sometimes ' $r$ ' values will be fake, that depends upon the selectivity and association of variables choose to test.

\begin{tabular}{|c|c|c|c|}
\hline \multicolumn{4}{|l|}{ P-values } \\
\hline Variables & Gdp(in cr.rs) & Fdi (in cr. Rs) & Fii (in cr. Rs.) \\
\hline Gdp(in cr.rs) & 0 & 0.001 & 0.961 \\
\hline Fdi(in cr.rs) & 0.001 & 0 & 0.930 \\
\hline Fii(in cr.rs) & 0.961 & 0.930 & 0 \\
\hline
\end{tabular}

Significance of $p$ - values :

Here the p- value between gdp and fdi is $0.001<\alpha$. So, there is a significant relation between fdi and gdp. It is also very clear that there is no significant relation between gdi and fii.

\begin{tabular}{|c|c|c|c|}
\hline \multicolumn{4}{|c|}{ Coefficients of determination } \\
\hline Variables & Gdp(in cr.rs) & Fdi (in cr. Rs) & Fii (in cr. Rs.) \\
\hline Gdp(in cr.rs) & 1 & 0.778 & 0 \\
\hline Fdi(in cr.rs) & 0.778 & 1 & 0.001 \\
\hline Fii(in cr.rs) & 0 & 0.001 & 1 \\
\hline
\end{tabular}

Coefficient of determination:

Coefficient of determination explains how much percentage of dependent variable can be explained by the independent variables can be explained by the independent variable. From the above result, it is clear that $77 \%$ of gdp can be explained by fdi.

\section{Summary \& Conclusion:-}

indian economy is one of the emerging economy with robust growth in terms of welcoming foreign investments not only to overcome current account deficit, these helping india to develop infrastructure, technology, innovations, employment and ripple the economic growth. Since two decades, the trend of indices like hdi, iip showing how india is moving as the best among the emerging economies. The policy makers focused and implemented the policies that are evitable to the sources of foreign investments and also for the sake of the country. But there are some areas left unfocussed/ to be implemented in case of fii investments. Because fii were the profit makers in stock market and active role players. Still they were not significantly caused to raise the economy as fdi do. The capital they were bringing to india is not stable. In this way, they were just causing stock exchanges to breeze and break. So, along with the tax relaxations and exceptions, there must be strict locking period for long term investment

\section{References:-}

1. Dr.syedtabassum sultana, prof.s.pardhasaradhi (2012), "impact of flow of fdi \& fii on indian stock market",financeresearch, vol no:3, july 2012, issn: 2165- 8226.

2. Mahantadevajit (2012), "impact of foreign direct investment on indian economy", research journal of management sciences, issn 2319-1171 vol. 1(2), 29-31, september (2012).

3. ,r.anitha(2012), "foreign direct investment and economic growth in india”, international journal of marketing, financial services \& management research vol.1 issue 8, august 2012, issn 22773622 .

4. Dr. Jasbirsingh,ms. Sumita chadha, dr. Anupama sharma (2012), "role of foreign direct investment in india: an 
analytical study", international journal of engineering and science issn: 2278-4721, vol. 1, issue 5 (october 2012), pp 34-42.

5. Bhavya malhotra (2014)," foreign direct investment: impact on indian economy", global journal of business management and information technology. Issn 2278-3679 volume 4, number 1 (2014), pp. 17-23 (C) research india publications.

6. Naveen sood (2015), "significance of fdi and fii for the economic growth of india: statistical analysis 20012015", international journal of applied research, 1 (13):570- 574,issn:2394-7500

7. Dr.syedtabassum sultana, prof. S.parthasaradhi (2012)," impact of fdi\& fii on indian stock market", finance research, vol.no:3, july 2012. Issn: 2165-8226.

8. ms. Fiona jeelani, prof. D.mukhopadhyay (2013), "globalization and the indian capital market", international journal of management and social science research, vol.no:2, august 2013, issn: 2319-4421.

9. https://www.bseindia.com

10. https://www.fpi.nsdl.co.in/web/reports/yearwise.aspx?rpttype $=5$

11. https://www.sebi.gov.in/sebiweb/home/homeaction.do?dolisting=yes\&sid=4 \&ssid=24\&smid=

12. https://www.moneycontrol.com/stocks/marketstats/activity.php?flag=fii

13. http://www.moneycontrol.com/stocks/hist_index_result.php?indian_indices=

14. https://www.moneycontrol.com/stocks/marketstats/activity.php?flag=fii\&mon th=200804201803

15. https://in.investing.com/indices/sensex-historical-data

16. https://www.nseindia.com/

17. https://www.rbi.org.in/scripts/bs_viewcontent.aspx?id=2513

18. www.sebi.in

19. www.dipp.org

20. www.rbiannualreports.com

21. www.moneycontrol.com

22. www.reserchjournals.com

23. www.timesofindia.com

24. www.imf.org 